\title{
Relative Incidence of Erwinia carotovora subsp. atroseptica in Stolon End and Peridermal Tissue of Potato Tubers in Canada
}

\author{
S. H. De Boer, Center for Animal and Plant Health, Canadian Food Inspection Agency, 93 Mount Edward Road, \\ Charlottetown, PE C1A 5T1, Canada
}

\begin{abstract}
De Boer, S. H. 2002. Relative incidence of Erwinia carotovora subsp. atroseptica in stolon end and peridermal tissue of potato tubers in Canada. Plant Dis. 86:960-964.

An enrichment enzyme-linked immunosorbent assay (ELISA) using monoclonal antibody 4F6, which is specific for the lipopolysaccharide antigen of serogroup I strains of Erwinia carotovora subsp. atroseptica, was used to detect the blackleg pathogen in potato seed lots after having confirmed that this serogroup is still the predominant strain of the pathogen in Canada. $E$. carotovora subsp. atroseptica was detected on $<6 \%$ of tubers in most seed lots, but the level of tuber contamination increased with the number of field generations. The incidence of E. carotovora subsp. atroseptica was generally greater in tissue taken from the stolon end of tubers than from peel samples, although there was a positive correlation between the bacterium's presence in the two sample types. The incidence of E. carotovora subsp. atroseptica in seed tuber lots was estimated from the results of tests on multiple composite samples, providing a cost effective approach for indexing seed lots for blackleg risk. The incidence of E. carotovora subsp. atroseptica was two and three times greater for both stolon end and peel samples, respectively, after harvest and storage of seed lots compared with tubers hand dug just before commercial harvesting, which suggests that the process whereby tubers become contaminated has both field and postharvest components.
\end{abstract}

Additional keywords: indexing, PCR, soft rot

The blackleg disease of potato is caused by the bacterium Erwinia carotovora subsp. atroseptica. Although it has been reported that blackleg-like symptoms also may be caused by E. carotovora subsp. carotovora and Erwinia chrysanthemi $(21,25)$, there is no evidence that these bacteria play a role in the epidemiology of blackleg in Canada.

Potato seed tubers are the chief source of inoculum for the blackleg disease. The work of Perombelon (26), in particular, has shown that E. carotovora subsp. atroseptica in seed tubers incites decay of the tuber after planting, and subsequent movement of the bacterium throughout the root zone of the plant results in contamination of progeny tubers, completing the cycle. Tuber lenticels are a particularly favorable niche for survival of the bacterium (1). However, the relationship between incidence and extent of tuber contamination and blackleg expression under field conditions not only differs among cultivars but also is affected by growing conditions (2).

In various aspects, the blackleg disease is similar to the other two major bacterial

Corresponding author: S. H. De Boer

E-mail: deboers@inspection.gc.ca

Accepted for publication 29 April 2002.

Publication no. D-2002-0708-01R

(C) 2002 Department of Agriculture and Agri-

Food, Government of Canada diseases of potato, namely bacterial ring rot and brown rot caused by Clavibacter michiganensis subsp. sepedonicus and Ralstonia solanacearum, respectively. For both ring rot and brown rot, the seed tuber is also the major inoculum source $(8,11)$. These bacteria are known to be present in the vascular tissue, from which they move to the developing plant and hence to the progeny tubers via the stolons. There has been little emphasis in blackleg studies on the presence of E. carotovora subsp. atroseptica in vascular tissue. Recently, however, Helias et al. (15) examined stolon tissue on plants grown from E. carotovora subsp. atroseptica-inoculated tubers and found the bacterium in almost all stolon samples and suggested that stolons were also an important contamination pathway. Perhaps E. carotovora subsp. atroseptica, like C. michiganensis subsp. sepedonicus and $R$. solanacearum, also has a significant vascular presence.

Since planting of pathogen-free seed tubers is an important control strategy for bacterial diseases of potato, there has been much emphasis on tuber indexing methods to differentiate among infected and noninfected potato seed lots. Indexing methodologies for ring rot and brown rot have almost exclusively focused on detection of the bacterium at the stolon attachment site of the tubers $(8,11,17)$. In contrast, indexing methodologies for blackleg have very much emphasized the potato periderm or peel as the site of bacterial inoculum $(3,13,16,18,34)$. Although the stolon end has not been entirely ignored as a site of contamination with E. carotovora subsp. atroseptica, it has not been specifically targeted for testing (29).

The possibility that there are two more or less independent populations of E. carotovora subsp. atroseptica associated with tubers must be considered-one population emanating from decaying seed pieces and causing external contamination of progeny tubers, and the other population originating from the vascular tissue of plants and migrating through the vascular tissue of stolons into the tuber. Even if the two populations are not strictly independent, their epidemiological importance may differ. In this study, we specifically evaluated incidence of E. carotovora subsp. atroseptica in the stolon end of tubers and compared this incidence with that detected in tuber peel.

\section{MATERIALS AND METHODS}

Tuber samples. Seed potato tubers from the provinces of Alberta, New Brunswick, and Prince Edward Island were tested for the presence of E. carotovora subsp. atroseptica either individually or as composite samples. For composite samples, the tissue from either 10 or 200 tubers was combined into a single sample.

Tubers, washed in running tap water, were sampled by removing a 0.5 -g coneshaped plug of tissue from around the stolon attachment site with a scalpel. Alternatively, a strip of 2-mm-thick peel tissue about $2 \mathrm{~cm}$ wide and 6 to $9 \mathrm{~cm}$ long, depending on the size of the tuber, was removed with a kitchen potato peeler. For experiments in which stolon ends and peel samples were compared, the same tubers were used for both samples. In other experiments, only stolon ends were sampled. Single stolon end samples or composites from 10 tubers were placed in plastic bags with equal amounts (vol/wt) of water and macerated by tapping with a mallet; composites of 200 stolon ends were macerated in a blender with equal amounts of water (vol/wt). Peel samples were crushed with a Pollähne press (MEKU, Wennigsen, Germany) and the sap collected in tubes for individual samples or combined for composite samples. The liquid phase from each of the different macerates was used for testing.

Isolation and characterization of $E$. carotovora subsp. atroseptica. Samples were streaked on crystal violet pectate (CVP) medium (4) prepared with Sunkist polypectate (no longer commercially avail- 
able) and incubated at $15^{\circ} \mathrm{C}$ for 3 to 4 days. Characteristic erwinia-like colonies were picked from the CVP medium and cultured from single colonies on nutrient agar until pure cultures were attained. Isolates were tested for growth on $\alpha$-methylglucoside, production of reducing substances from sucrose, growth at $37^{\circ} \mathrm{C}$, and phosphatase activity as described (6).

Enrichment. Samples were enriched for E. carotovora subsp. atroseptica by adding $100 \mu \mathrm{l}$ of sample to $1 \mathrm{ml}$ of polypectate enrichment medium (6) and incubating at $15^{\circ} \mathrm{C}$ for 3 to 4 days.

Enzyme-linked immunosorbent assay (ELISA). Samples were tested by ELISA both before and after enrichment. An indirect sandwich ELISA procedure was used with monoclonal antibody 4F6, specific for serogroup I of E. carotovora subsp. atroseptica (7). The procedure was modified as follows. Fifty $\mu$ l of sample buffer $(0.05 \mathrm{M}$ phosphate buffer $\mathrm{pH} 7.2,0.85 \% \mathrm{NaCl}, 2 \%$ polyvinylpyrrolidone, $0.2 \%$ skim milk powder, $0.05 \%$ Tween 80 ) was loaded in wells of polystyrene plates previously coated with trapping polyclonal antibody prior to loading the sample. Samples were incubated overnight at $4^{\circ} \mathrm{C}$, but the monoclonal antibody and alkaline phosphataseantibody conjugate were each incubated for $1 \mathrm{~h}$ at $37^{\circ} \mathrm{C}$. The $p$-nitrophenylphosphate substrate was incubated for $1 \mathrm{~h}$ at room temperature before reading absorbance at $405 \mathrm{~nm}$. Each plate was loaded with two positive and two negative control samples consisting of lyophilized bacterial supernatant fluid adjusted to give a constant absorbance reading and healthy potato extract, respectively. Sample absorbance values were transformed by $\mathrm{Yt}=(\mathrm{Yx}$ - Yn)/(Yp - Yn), where Yt is the transformed value, $Y x$ the absorbance reading, Yn the mean of the absorbance of the negative controls, and Yp the mean absorbance of the positive controls. Yt values greater than or equal to 0.06 were considered positive.

Polymerase chain reaction (PCR). PCR amplification was done on a limited number of samples using primers ECA1f and ECA1r as described (10).

Estimation of incidence. To determine the incidence of E. carotovora subsp. atroseptica in a potato lot, 40 composite samples of 10 tubers were tested. The incidence, as the percentage of contaminated or infected tubers in a seed lot, was estimated from the probability of detecting one or more positive tubers in a composite sample. The incidence $(I)$ was calculated by $I=\left\{1-[(N-p) / N]^{1 / n}\right\} 100$, where $p$ is the number of composites that tested positive for E. carotovora subsp. atroseptica, $N$ the total number of composites tested, and $n$ the number of tubers combined into a composite sample (23).

\section{RESULTS}

Preliminary experiments. To confirm that the blackleg disease in Canada was still chiefly caused by serogroup I of $E$. carotovora subsp. atroseptica, as was determined previously (9), 71 potato stems with blackleg-like symptoms representing 19 different seed potato lots were tested for reaction with monoclonal antibody $4 \mathrm{~F} 6$ in ELISA. Of these, $91.5 \%$ tested positive.

Since ELISA was the method of choice for testing large numbers of seed potato lots in a cost-effective manner, adequacy of ELISA was investigated by applying confirmatory tests on preliminary samples. The presence of E. carotovora subsp. atroseptica was confirmed in more than $70 \%$ of the samples that were positive in ELISA with and without prior enrichment by isolation of E. carotovora subsp. atroseptica on CVP medium (Table 1). About $80 \%$ of ELISA-positive samples could be confirmed by PCR amplification of a 690-bp DNA fragment using E. carotovora subsp. atroseptica-specific primers (Table 1).

ELISA with and without enrichment. Extracts from many of the seed potato lots in this study were tested by ELISA both with and without prior enrichment. Detection limits of ELISA and enrichmentELISA are known to be in the range of $10^{5}$ to $10^{6}$ cells per $\mathrm{ml}$ and $10^{2}$ to $10^{3}$ cells per $\mathrm{ml}$, respectively (19). As expected, with the prior enrichment, E. carotovora subsp. atroseptica was found in more samples than without enrichment. In four sets of seed lots, E. carotovora subsp. atroseptica was detected in two to three times as many lots with prior enrichment compared with the number found without enrichment (Table 2).

Detection of $E$. carotovora subsp. atroseptica in stolon samples from seed tubers. In 1994, 400 tubers from each of 886 seed lots grown in New Brunswick were tested as two composite samples of stolon end tissue from 200 tubers by ELISA without enrichment. The samples were collected and processed for regulatory bacterial ring rot testing according to a standard protocol (8), and the homogenate was tested in ELISA for the presence of $E$. carotovora subsp. atroseptica in addition to the test for $C$. michiganensis subsp. sepedonicus. Seed lots were grouped according to certification class, which generally represents the number of field generations of the seed lot. The number of lots positive for E. carotovora subsp. atroseptica varied from $9 \%$ for seed in the Elite I class (second field generation) to $30 \%$ for the Certified class (seventh field generation) (Fig. 1). For the remaining seed lots, the level of positive reactions varied from 13 to $18 \%$. There was a significant correlation $\left(R^{2}=0.722\right)$ between the number of seed lots with E. carotovora subsp. atroseptica and number of field generations.

Relative incidence of $E$. carotovora subsp. atroseptica in stolon and peel samples. The incidence of E. carotovora subsp. atroseptica in stolon end and peel samples within seed lots was assessed during 1998 and 1999 using 12 seed lots from Alberta and 50 lots from Prince Edward Island (PEI). For each seed lot, 400 tubers were tested by enrichment ELISA in composites of 10 stolon end and 10 peel samples. The incidence in a seed lot was estimated on the basis of the number of positive composite stolon end and peel samples (Table 3). E. carotovora subsp. atroseptica was not detected in either peel

Table 1. Confirmatory tests to substantiate results from enzyme-linked immunosorbent assay (ELISA) for the detection of Erwinia carotovora subsp. atroseptica in potato tissue

\begin{tabular}{llcc}
\hline ELISA method & \multicolumn{1}{c}{$\begin{array}{c}\text { Confirmation test } \\
\text { method }^{\text {a }}\end{array}$} & Samples (no.) & $\begin{array}{c}\text { Percent confirmed } \\
\text { positive }\end{array}$ \\
\hline Without enrichment & Isolation on CVP & 17 & 76.5 \\
& PCR amplification & 11 & 81.8 \\
With enrichment & Isolation on CVP & 49 & 71.4 \\
& PCR amplification & 39 & 79.5 \\
\hline
\end{tabular}

${ }^{\text {a }} \mathrm{CVP}=$ crystal violet pectate $\mathrm{PCR}=$ polymerase chain reaction .

Table 2. Comparison of number of seed lots found to contain Erwinia carotovora subsp. atroseptica by enzyme-linked immunosorbent assay (ELISA) with and without prior enrichment of tissue extracts

\begin{tabular}{|c|c|c|c|c|c|}
\hline \multirow[b]{3}{*}{$\begin{array}{l}\text { Set of seed } \\
\text { lots }\end{array}$} & \multirow[b]{3}{*}{$\begin{array}{c}\text { Seed lots } \\
\text { in set (no.) }\end{array}$} & \multicolumn{4}{|c|}{ Positive seed lots (no.) ${ }^{\mathrm{a}}$} \\
\hline & & \multicolumn{2}{|c|}{ Non-enriched-ELISA } & \multicolumn{2}{|c|}{ Enriched-ELISA } \\
\hline & & Peel tissue & $\begin{array}{l}\text { Stolon end } \\
\text { tissue }\end{array}$ & Peel tissue & $\begin{array}{l}\text { Stolon end } \\
\text { tissue }\end{array}$ \\
\hline $\bar{A}$ & 12 & 4 & 5 & 6 & 7 \\
\hline B & 23 & 0 & 2 & 5 & 12 \\
\hline $\mathrm{C}$ & 23 & 6 & 8 & 14 & 15 \\
\hline D & 50 & 6 & 11 & 19 & 25 \\
\hline Total & 108 & 16 & 26 & 44 & 57 \\
\hline
\end{tabular}

${ }^{a}$ Number of seed lots in which E. carotovora subsp. atroseptica serogroup I was detected by ELISA in tissue samples taken from the stolon end and peel of the same tubers. 
or stolon end samples in $8 \%$ of the Alberta seed lots and $18 \%$ of the seed lots from PEI. Incidence of E. carotovora subsp. atroseptica was generally low in lots in which it was found; the highest incidence being 30\% in an Elite 3 seed lot from PEI (Table 3). There were 11 seed lots in which it was found only in the stolon end samples but not in the peel samples, while there were only three lots in which it was found in the peel samples but not in the stolon end samples. Nevertheless, there was significant correlation $\left(R^{2}=0.797\right)$ between the overall incidence in stolon end and peel samples of a given tuber lot (Fig. 2).

Impact of harvesting on $\boldsymbol{E}$. carotovora subsp. atroseptica contamination. It has been suggested that potato tubers may acquire E. carotovora subsp. atroseptica contamination postharvest through the harvesting and grading procedures in addition to the field acquisition of the bacterium (12). Hence, we tested tubers before normal harvest by hand digging tubers directly from the field and resampling the same lots after they had been harvested, graded, and placed in storage. Both preand postharvest samples were stored at $4{ }^{\circ} \mathrm{C}$ for 5 to 6 months before testing by enrichment-ELISA. The frequency with which $E$. carotovora subsp. atroseptica was detected was higher for the postharvest samples for both peel and stolon end samples compared with preharvest values (Table 4). Incidence of E. carotovora subsp. atroseptica differed among cultivars with Sebago, a cultivar known to be particularly susceptible to blackleg, having a higher incidence of $E$. carotovora subsp. atroseptica than other cultivars. Overall the incidence in peel samples was threefold greater for postharvest than for preharvest samples, and the difference was twofold for stolon end samples (Table 4).

\section{DISCUSSION}

In $1987,96 \%$ of isolates of E. carotovora subsp. atroseptica from blackleg-

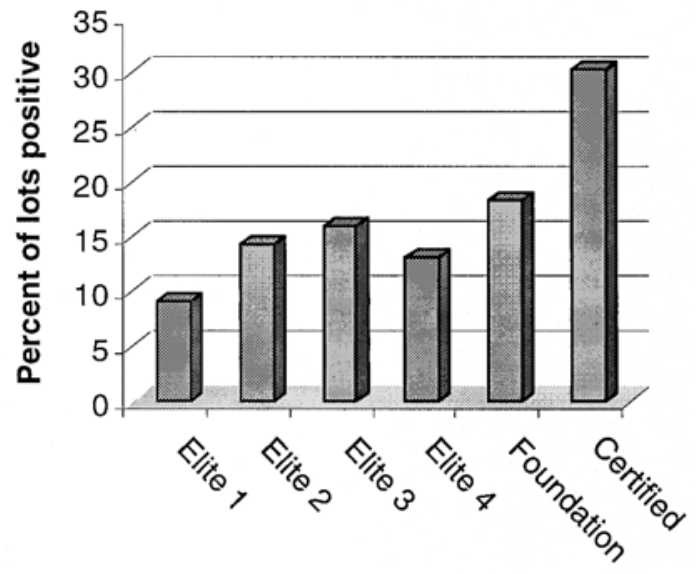

\section{Seed Class}

Fig. 1. Percentage of lots in different classes of seed potatoes grown in New Brunswick in which Erwinia carotovora subsp. atroseptica serogroup I was detected by enzyme-linked immunosorbent assay (ELISA). Tests were conducted on two composite samples per seed lot, each containing 200 stolon ends. Seed lots included 52 cultivars, and number of lots per seed class tested were 22 for Elite 1, 105 for Elite 2, 288 for Elite 3, 281 for Elite 4, 147 for Foundation, and 43 for Certified.

infected plants in Canada were serogroup I (9). Serogroup I has also been the predominant type in several other countries. Recently, however, it was reported in Poland (31) that the proportion of serogroup I strains in blackleg-infected plants was lower, at about $65 \%$, and this is perhaps also true elsewhere. Our results indicate that serogroup I was still the predominant E. carotovora subsp. atroseptica type associated with blackleg in Canada. In Europe, some of the blackleg-like symptoms are caused by E. chrysanthemi (32). Although E. chrysanthemi has never been associated with potato in Canada, we tested 50 seed lots in ELISA with monoclonal antibody 6A6 (30) specific for E. chrysanthemi but found no positives (unpublished data), confirming that this species is not associated with potato in Canada.

Efficacy of ELISA for detecting E. carotovora subsp. atroseptica in potato tubers depends on the serological specificity of the antibody and the sensitivity of the test. Monoclonal antibodies to the lipopolysaccharide of E. carotovora subsp. atroseptica are highly specific but may cross-react with a few other bacteria common in the soil environment (33). While it is doubtful that these other bacteria achieve adequate populations to be detectable by ELISA, there is a possibility that false positive ELISAs could occur. The results of our confirmatory tests suggest that ELISA is reasonably accurate in detecting true $E$. carotovora subsp. atroseptica-positive samples (Table 1). It must be kept in mind, also, that the confirmatory tests themselves have their difficulties. The isolation procedure on the CVP semiselective medium may be limited by overgrowth or inhibition by saprophytic bacteria that inevitably compete with the target bacterium. PCR amplification, too, is prone to give false negative results due to inhibitory substances in sample extracts.

The limitation in sensitivity of the ELISA is overcome to a great extent by using enrichment-ELISA (19). This ap-

Table 3. Incidence of Erwinia carotovora subsp. atroseptica in the periderm and stolon end of tubers in potato lots of different seed classes from Alberta and Prince Edward Island

\begin{tabular}{|c|c|c|c|c|c|c|c|}
\hline \multirow[b]{3}{*}{ Seed class } & \multirow[b]{3}{*}{ Total lots } & \multicolumn{6}{|c|}{ Incidence (\%) of $E$. carotovora subsp. atroseptica ${ }^{\text {a }}$} \\
\hline & & \multicolumn{3}{|c|}{ Peel tissue } & \multicolumn{3}{|c|}{ Stolon end tissue } \\
\hline & & $\underset{\text { lots }}{\text { Contaminated }}$ & $\begin{array}{c}\text { Mean } \\
\text { incidence }\end{array}$ & $\begin{array}{c}\text { Incidence among } \\
\text { positives }\end{array}$ & $\underset{\text { lots }}{\text { Contaminated }}$ & $\begin{array}{c}\text { Mean } \\
\text { incidence }\end{array}$ & $\begin{array}{c}\text { Incidence among } \\
\text { positives }\end{array}$ \\
\hline \multicolumn{8}{|l|}{ Alberta } \\
\hline Pre-Elite & 1 & 0 & 0 & na & 0 & 0 & na \\
\hline Elite 1 & 3 & 1 & 0.13 & 0.4 & 3 & 0.37 & $0.3-0.4$ \\
\hline Elite 2 & 4 & 3 & 0.25 & $0.3-0.4$ & 2 & 0.28 & $0.3-0.8$ \\
\hline Elite 3 & 4 & 2 & 0.75 & $0.5-2.5$ & 2 & 1.18 & $2.2-2.5$ \\
\hline \multicolumn{8}{|c|}{ Prince Edward Island } \\
\hline Elite 1 & 9 & 1 & 0.14 & 1.24 & 6 & 0.28 & $0.25-0.78$ \\
\hline Elite 2 & 9 & 3 & 0.73 & $0.25-5.70$ & 3 & 1.03 & $1.91-4.22$ \\
\hline Elite 3 & 14 & 10 & 5.97 & $0.25-30.12$ & 11 & 3.68 & $0.25-16.40$ \\
\hline Elite 4 & 10 & 7 & 5.55 & $0.51-17.28$ & 10 & 5.43 & $0.25-18.77$ \\
\hline Foundation & 8 & 7 & 3.56 & $0.53-16.00$ & 8 & 1.88 & $0.25-5.38$ \\
\hline
\end{tabular}

a Percentage of tubers within a seed lot that were contaminated with E. carotovora subsp. atroseptica serogroup I as estimated from the number of composite samples out of 40 that were positive by enrichment enzyme-linked immunosorbent assay (ELISA). 
proach has been quite successful, not only for pectolytic erwinias, but also for other pathogenic bacteria for which there are good semiselective enrichment media (20). We found E. carotovora subsp. atroseptica in two to three times as many seed lots using enrichment-ELISA than using ELISA on the raw extract without enrichment (Table 2).

Notwithstanding its limitations, enrichment-ELISA could be used to provide a relative estimation of the incidence of $E$. carotovora subsp. atroseptica in seed lots. E. carotovora subsp. atroseptica was detected in only about half of the tuber lots examined (Table 2), and when it was detected, the incidence was very low (Table $3)$. The low incidence at which E. carotovora subsp. atroseptica was detected is consistent with the low level of blackleg that occurs in potato in Canada. Previously, the incidence of blackleg was greatly diminished by the use of pathogen-tested stem cuttings to initiate the nuclear level of seed potatoes (5). Today, stem cuttings have been replaced by pathogen-tested micropropagated plantlets and minitubers to initiate seed tuber lots. This appears to have been an effective approach in further reducing the occurrence of blackleg and is similar to the decrease in incidence of blackleg in other geographic areas where pathogen-tested propagules have been used (27). The observation that most seed potato tubers are contaminated with $E$. carotovora subsp. atroseptica (26) is not true of Canadian seed potatoes today.

The reduction in blackleg by the use of E. carotovora subsp. atroseptica-free planting material is consistent with the notion that the primary inoculum source is the seed tuber. The disease can be controlled by eliminating the seed tuber as an inoculum source as is done for the bacterial ring rot (8) and brown rot diseases (11). Disease reduction, however, has not translated into disease eradication. E. carotovora subsp. atroseptica-free material set out in the field sometimes becomes contaminated, as evidenced by the detection of E. carotovora subsp. atroseptica on seed lots in this study and the occasional find of blackleg in the field. The presence of $E$. carotovora subsp. atroseptica on Elite 1 seed lots (Fig. 1) representing the second field generation suggests that contamination can occur early on in the field environment. The number of seed lots contaminated increased with the number of generations in the field (Fig. 1).

The initial source of E. carotovora subsp. atroseptica that contaminates or infects clean stocks is unclear. Reports in the literature had suggested that surface contamination of tubers may result from contact with inoculum on harvesters or grading lines contaminated from as little as a single infected tuber (12). In our study, we indeed found almost threefold higher levels of E. carotovora subsp. atroseptica contamination in potatoes that had been harvested, graded, and stored by normal agronomic practices compared with tubers hand dug from the field (Table 4). However, we also found a twofold increase in the incidence of E. carotovora subsp. atroseptica in stolon end samples in normally harvested tubers compared with preharvest hand dug tubers. This latter increase is more difficult to explain by mere contact with an inoculum source. Perhaps this increase was due to lateseason movement or multiplication of bacteria in the stolons. In any case, the source of the initial inoculum needs to be investigated. Although E. carotovora subsp. carotovora is known to survive in the soil environment and in surface water, $E$. carotovora subsp. atroseptica is seldom encountered in studies of pectolytic erwinia in the environment $(14,22,24)$.

The incidence of E. carotovora subsp. atroseptica in stolon end samples tended to be higher than the incidence in peel samples. For the bacterial ring rot and brown

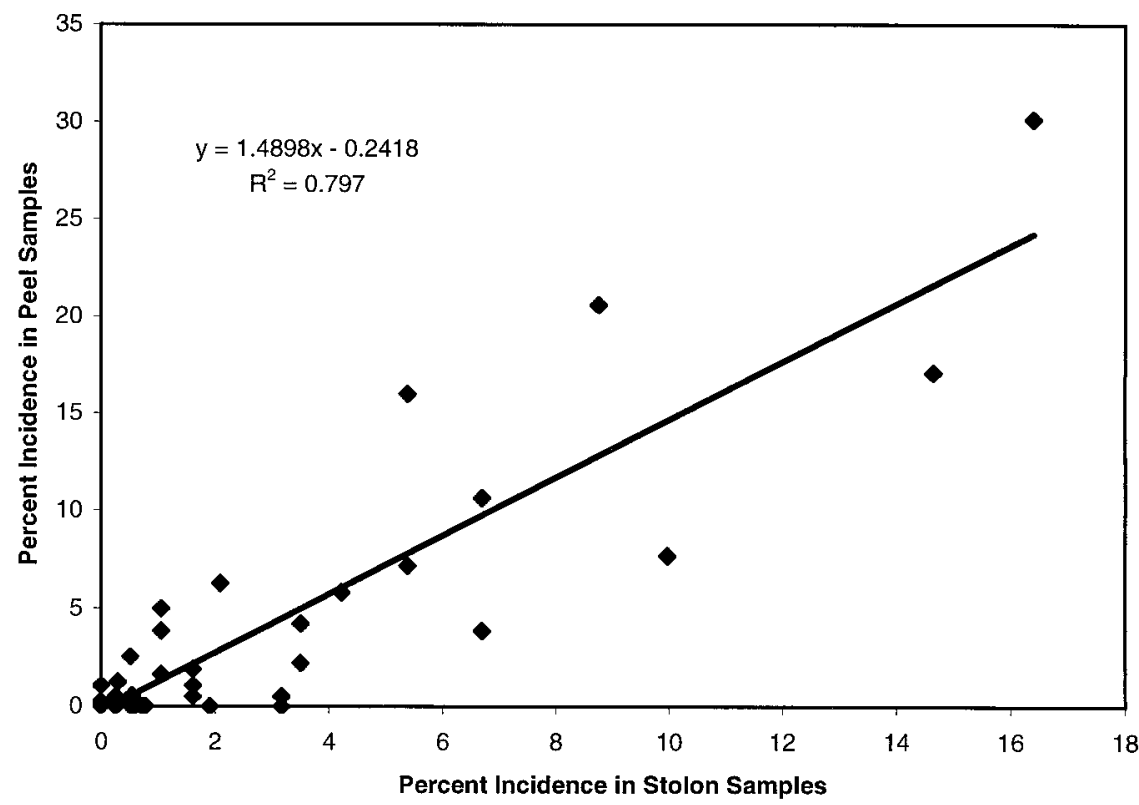

Fig. 2. Comparison of the incidence of Erwinia carotovora subsp. atroseptica in stolon samples with the incidence in peel samples for seed lots from Prince Edward Island tested by the enrichment enzyme-linked immunosorbent assay (ELISA) procedure.

Table 4. Frequency of Erwinia carotovora subsp. atroseptica in potato peel and stolon end samples for tubers collected prior to and after harvest

\begin{tabular}{|c|c|c|c|c|c|}
\hline \multirow[b]{3}{*}{ Cultivar } & \multirow{3}{*}{$\begin{array}{c}\text { Composites } \\
\text { tested }\end{array}$} & \multicolumn{4}{|c|}{ Positive composite samples (no.) ${ }^{a}$} \\
\hline & & \multicolumn{2}{|c|}{ Peel samples } & \multicolumn{2}{|c|}{ Stolon end samples } \\
\hline & & Preharvest & Postharvest & Preharvest & Postharvest \\
\hline Russet Burbank & 160 & 0 & 1 & 14 & 15 \\
\hline Russet Norkota & 160 & 0 & 2 & 4 & 12 \\
\hline Sebago & 120 & 14 & 32 & 12 & 22 \\
\hline Shepody & 80 & 0 & 3 & 0 & 4 \\
\hline Superior & 120 & 1 & 7 & 0 & 6 \\
\hline Other & 240 & 10 & 28 & 12 & 18 \\
\hline Total & 880 & 25 & 73 & 42 & 77 \\
\hline
\end{tabular}

${ }^{a}$ Number of composite samples of tuber stolon ends and peels in which E. carotovora subsp. atroseptica serogroup I was detected by enrichment enzyme-linked immunosorbent assay (ELISA).

${ }^{\mathrm{b}}$ Composites were of 10 tubers each. rot pathogens, it is assumed that they rein the stolon end of tubers, having E. carotovora subsp. atroseptica has not been ascertained. The finding of the pathogen in stolons by Helias et al. (15) adds cossibility that indeed it is in the absence of overt symptoms of disease. Stolon-transmitted bacteria would necessarily be associated with the vascular tissue of the tubers. Perhaps such vascularused for seed and cause blackleg disease more readily than populations harbored in the lenticels and other protected niches on the tuber surface.

The populations of E. carotovora subsp. significant implications for strategies to index seed tuber lots for the presence of the bacteria. Methodologies to index for ring rot and brown rot by sampling tuber stolons, but whether to developing stems when the tuber 
stolon ends have been well developed and used extensively $(8,11)$. This approach could be used equally well for detecting $E$. carotovora subsp. atroseptica in stolon ends. One important difference is that $E$. carotovora subsp. atroseptica does not have a zero tolerance like ring rot and brown rot. Hence, it is not enough to simply detect the pathogen; there is a need to establish its incidence when present. Testing large numbers of tubers individually would be prohibitively costly, and testing in composites of 200 tubers as for ring rot and brown rot would not provide incidence levels. It may, however, be feasible to use the approach taken in this study. Per seed lot, we tested 40 composite samples of 10 tubers each. For independent random samples, the incidence in a lot can be estimated from the number of positive composite samples if the incidence is low enough ( $<30 \%$ if 40 composites are used) to avoid multiple positive tubers per composite sample. This approach with the ELISA procedure is feasible and of reasonable cost. In geographic areas where multiple or unknown serotypes of $E$. carotovora subsp. atroseptica occur, other testing strategies may need to be used, such as PCR testing (13) or isolation procedures (28).

\section{ACKNOWLEDGMENTS}

I thank Alain Boucher and Debbie Fujimoto for coordinating the sampling of the New Brunswick and Alberta seed lots, respectively, and the staff of the Diagnostic Laboratory of the Centre of Expertise for Potato Diseases, Charlottetown, for conducting many of the tests required for this study. Thanks also to Jeanette D'Aubin and Len Ward for technical assistance. The funding provided by Potato Development Inc., Alberta, for a portion of this study is appreciated.

\section{LITERATURE CITED}

1. Adams, M. J. 1975. Potato tuber lenticels: Susceptibility to infection by Erwinia carotovora var. atroseptica and Phytophthora infestans. Ann. Appl. Biol. 79:275-282.

2. Bain, R. A., Perombelon, M. C. M., Tsror, L., and Nachmias, A. 1990. Blackleg development and tuber yield in relation to numbers of Erwinia carotovora subsp. atroseptica on seed potatoes. Plant Pathol. 39:125-133.

3. Chard, J. M., and Oxley, S. J. P. 1989. Comparison of methods for estimating Erwinia carotovora numbers on potato tubers. J. Appl. Bacteriol. 67:19-23.

4. Cuppels, D. A., and Kelman, A. 1974. Evaluation of selective media for isolation of soft rot bacteria from soil and plant tissue. Phytopathology 64:468-475.

5. De Boer, S. H. 1983. Frequency and distribution of Erwinia carotovora serogroups associated with potato in the Pemberton Valley of British Columbia. Can. J. Plant Pathol. 5:270-284.

6. De Boer, S. H., and Kelman, A. 2001. Erwinia soft rot group. Pages 56-72 in: Laboratory Guide for Identification of Plant Pathogenic Bacteria, 3rd ed. N. W. Schaad, J. B. Jones, and W. Chun, eds. American Phytopathological Society, St. Paul, MN.

7. De Boer, S. H., and McNaughton, M. E. 1987.
Monoclonal antibodies to the lipopolysaccharide of Erwinia carotovora subsp. atroseptica serogroup I. Phytopathology 77:828-832.

8. De Boer, S. H., Stead, D. E., Alivizatos, A. S., Janse, J. D., Van Vaerenbergh, J., De Haan, T. L., and Mawhinney, J. 1994. Evaluation of serological tests for detection of Clavibacter michiganenesis subsp. sepedonicus in composite potato stem and tuber samples. Plant Dis. 78:725-729.

9. De Boer, S. H., Verdonck, L., Vruggink, H., Harju, P., Bang, H. O., and De Ley, J. 1987. Serological and biochemical variation among potato strains of Erwinia carotovora subsp. atroseptica and their taxonomic relationship to other E. carotovora strains. J. Appl. Bacteriol. 63:487-495.

10. De Boer, S. H., and Ward, L. J. 1995. PCR detection of Erwinia carotovora subsp. atroseptica associated with potato tissue. Phytopathology 85:854-858.

11. Elphinstone, J. G., Hennnessy, J., Wilson, J. K., and Stead, D. E. 1996. Sensitivity of different methods for the detection of Ralstonia solanacearum in potato tuber extracts. EPPO Bull. 26:663-679.

12. Elphinstone, J. G., and Perombelon, M. C. M. 1986. Contamination of potatoes by Erwinia carotovora during grading. Plant Pathol. 35:25-33.

13. Frechon, D., Exbrayat, P., Helias, V., Hyman, L. J., Jouan, B., Llop, P., Lopez, M. M., Payet, N., Perombelon, M. C. M., Toth, I. K., Van Beckhoven, J. R. C. M., van der Wolf, J. M., and Bertheau, Y. 1998. Evaluation of a PCR kit for the detection of Erwinia carotovora subsp. atroseptica on potato tubers. Potato Res. 41:163-173.

14. Harrison, M. D., Quinn, C. E., Sells, I. A., and Graham, D. C. 1977. Waste potato dumps as sources of insects contaminated with soft rot coliform bacteria in relation to recontamination of pathogen-free potato stocks. Potato Res. 20:37-52.

15. Helias, V., Andrivon, D., and Jouan, B. 2000. Internal colonization pathways of potato plants by Erwinia carotovora ssp. atroseptica. Plant Pathol. 49:33-42.

16. Hyman, L. J., Dewasmes, V., Toth, I. K., and Perombelon, M. C. M. 1997. Improved PCR detection sensitivity of Erwinia carotovora subsp. atroseptica in potato tuber peel extract by prior enrichment on a selective medium. Lett. App. Microbiol. 25:143-147.

17. Janse, J. D. 1988. A detection method for Pseudomonas solanacearum in symptomless potato tubers and some data on its sensitivity and specificity. EPPO Bull. 18:343-351.

18. Jones, D. A., Hyman, L. J., Tumeseit, M., Smith, P., and Perombelon, M. C. M. 1994. Blackleg potential of potato seed: Determination of tuber contamination by Erwinia carotovora subsp. atroseptica by immunofluorescence colony staining and stock and tuber sampling. Ann. Appl. Biol. 124:557-568.

19. Lopez, M. M., Cambra, M., Gorris, M. T., and Perombelon, M. C. M. 1998. Enrichment ELISA (E-ELISA). Pages 28-35 in: Methods for the Detection and Quantification of Erwinia carotovora subsp. atroseptica on Potatoes: A Laboratory Manual. M. C. M. Perombelon and J. M. van der Wolf, eds. Scottish Crop Res. Inst. Occasional Publ. No. 10.

20. Lopez, M. M., Gorris, M. T., Culbero, J., and Cambra, M. 1997. Selective enrichment improves the isolation, serological and molecular detection of plant pathogenic bacteria. Pages 117-122 in: Diagnosis and Identifica- tion of Plant Pathogens. H. Dehn et al., eds. Kluwer Academic Publishers, Dordrecht, Netherlands.

21. Lumb, V. M., Perombelon, M. C. M., and Zutra, D. 1986. Studies of a wilt disease of the potato plant in Israel caused by Erwinia chrysanthemi. Plant Pathol. 25:196-202.

22. Maddox, D. A., and Harrison, M. D. 1988. Presence and population dynamics of Erwinia carotovora in irrigation water in south central Colorado. J. Appl. Bacteriol. 64:169-182.

23. Masmoudi, K., Duby, C., Suhas, M., Guo, J. Q., Guyot, L., Olivier, V., Taylor, J., and Maury, Y. 1994. Quality control of pea seed for pea seed borne mosaic virus. Seed. Sci. Technol. 22:407-414

24. McCarter-Zorner, N. J., Harrison, M. D., Granc, G. D., Quinn, C. E., Sells, I. A., and Graham, D. C. 1985. Soft rot Erwinia bacteria in the rhizosphere of weeds and crop plants in Colorado, United States and Scotland. J. Appl. Bacteriol. 59:357-368.

25. Molina, J. J., and Harrison, M. D. 1977. The role of Erwinia carotovora in the epidemiology of potato blackleg. I. Relationship of $E$. carotovora var. carotovora and E. carotovora var. atroseptica to potato blackleg in Colorado. Am. Potato J. 54:587-591.

26. Perombelon, M. C. M. 1992. Potato blackleg: Epidemiology, host-pathogen interaction and control. Neth. J. Plant Pathol. 98:135-146.

27. Perombelon, M. C. M. 2000. Blackleg risk potential of seed potatoes determined by quantification of tuber contamination by the causal agent and Erwinia carotovora subsp. atroseptica: A critical review. EPPO Bull. 30:413-420.

28. Perombelon, M. C. M., and Hyman, L. J. 1986. A rapid method to identify and quantify soft rot erwinias directly from plant material based on their temperature tolerances and sensitivity to erythromycin. J. Appl. Bacteriol. 60:61-66.

29. Perombelon, M. C. M., and van der Wolf, J. M. 1998. Potato tuber peel extract preparation and detection probes. Pages 3-10 in: Methods for the Detection and Quantification of $\mathrm{Er}$ winia carotovora subsp. atroseptica on Potatoes: A Laboratory Manual. M. C. M. Perombelon and J. M. van der Wolf, eds. Scottish Crop Res. Inst. Occasional Publ. No. 10.

30. Singh, U., Trevors, C. M., De Boer, S. H., and Janse, J. D. 2000. Fimbrial-specific monoclonal antibody-based ELISA for European potato strains of Erwinia chrysanthemi and comparison to PCR. Plant Dis. 84:443-448.

31. Sledz, W., Jafra, S., Waleron, M., and Lojkowska, E. 2000. Genetic diversity of Erwinia carotovora strains isolated from infected plants grown in Poland. EPPO Bull. 30:403-407.

32. van der Wolf, J. M. 1994. Evaluation of serological methods for detection of $E r$ winia chrysanthemi in potato peel extracts. Ph.D. thesis. Rijksuniversiteit, Leiden, Netherlands.

33. van der Wolf, J. M., Kastelein, P., van Beckhoven, J. C. M., van den Brink, M., and de Vries, P. M. 1996. Verification of immunofluorescence colony-staining of Erwinia carotovora subsp. atroseptica by reisolation and immunodiffusion or PCR. EPPO Bull. 26:707-715.

34. van Vuurde, J. W. L., and de Vries, P. M. 1994. Population dynamics of Erwinia carotovora subsp. atroseptica on the surface of intact and wounded seed potatoes during storage. J. Appl. Bacteriol. 76:568-575. 